\title{
A Sociolinguistic Investigation of Social Stratification and Linguistic Variation among the Kashmiri Speech Community
}

\author{
Nisar Ahmad Koka \\ Department of English, Faculty of Languages and Translation, King Khalid University, Abha, Kingdom of Saudi \\ Arabia (KSA)
}

\begin{abstract}
This paper is restricted to the investigation of linguistic variation among the Kashmiri speakers at the level of phonology and lexicon of their language in accordance with certain social variables, viz-a-viz. religion, education, region / socioeconomic status, age and occupation. In the present paper, an effort has been devoted to examine as to how the structure of the Kashmiri language varies at the level of phonology and lexicon, in accordance with above mentioned social variables. It also takes into account the possible reasons behind this variation. The present paper explores as to how the social heterogeneity of the Kashmiri speech community is reflected in the linguistic behavior of its speakers, and gives rise to variations in the use of their language at the level of phonology and lexicon. The paper begins with giving a brief introduction about language variation, social variables, and linguistic variables. It also discusses the historical perspective of language variation, and throws light on the related literature by discussing some important studies of variation carried out by different scholars of linguistics from time to time. In this study an attempt has been made to picturize the social structure of the Kashmiri speech community in terms of its social stratification/ and social heterogeneity. The paper also discusses the research methodology adopted in carrying out this study.
\end{abstract}

Index Terms-social heterogeneity, linguistic variation, linguistic variables, sociolinguistic variables, speech community, registers, phonological variation, lexical variation

\section{INTRODUCTION}

During the last few decades sociolinguistics has emerged as an autonomous field of study and research. It has gained a global momentum and has been recognized all over the world. It is rightly concerned with the ways in which language interacts in a society and functions in a particular social set up. The scholars of sociolinguistics have been taking keen interest in language problems like language use in multilingual settings, language maintenance and language shift, language standardization and language modernization, language and culture, ethnography of communication, communicative competence, language choice, language change, language variation etc.

Linguistic variation is central to the study of language use. It is an inherent property of almost all widely used languages of the world. In fact, it is impossible to study the language forms used in natural atmosphere without being confused with the issue of linguistic variation. Languages vary according to the social characteristics of the speakers. They also vary according to the situations in which their users find themselves. No living language can afford to remain static. It must vary according to given social circumstances.

Right from the beginning of the second half of the twentieth century, language variation has been the focus of attention for linguists, sociolinguists, and language scientists. It has emerged out to be a fascinating field of research and enquiry right from the emergence of sociolinguistics. It has fascinated and continues to fascinate a lot of people with a wide variety of backgrounds. Language variation in sociolinguistics refers to variation in linguistic items in accordance with social variation. The social factors such as religion, region, education, age, occupation, socioeconomic levels/status etc. are responsible for variation in language and the resultant linguistic items are called linguistic or sociolinguistic variables. Since language variation takes place because of social variation, the linguistic and social variables are correlated.

\section{A. Historical Perspective of Language Variation}

The history of varying property of language is of course as old as the language itself. This property of language has always been a subject of discussion among a large number of language researchers and language scientists from time to time. The early well documented record of research in this field dates back to the first half of the twentieth century. These records are mainly associated with Edward Sapir (1915) and K. Jaberg (1936). However towards the second half of the twentieth century, the credit for carrying out the empirical work for the first time in this regard goes to William Labov.

Peter Trudgill (1983) argues that the first and foremost study related to field of 'language and society', which serves the linguistic purpose, is the empirical study of 'sound change '.This study of sound change was carried out by William 
Labov in 1961 in a very small island called Maratha's Vineyard. This study of Labov is generally regarded as pioneering work in studying language in relation to its social context. In his study of Mratha's Vineyard, Labov (1972, chapters 1 and 7) logically described the existence of systematic differences among the speakers in their use of certain linguistic variables. Peter Trudgill (1983) admits that " much work of this type falls within the framework established first and foremost by William Labov, and consists of work which Labov himself has sometimes referred to as secular linguistics" (Trudgill, 1983, pp. 2-3).

In fact, it is dialectology which has been the main source of evidence for the social history of speech variation. Moreover, there are a considerable number of studies, investigations, and surveys, exploring the relationship between speech and social groups. In their investigations on Italian dialects k. Jaberg (1915) and Jacob (1936) Jude have observed considerable variations among the speakers of different groups speaking these dialects (Gumperz, 1971, p. 79)

\section{B. Review of the Related Literature}

As stated earlier, the phenomenon of linguistic variation has always attracted the attention of sociolinguists. It has also been the subject of debate and discussion among various sociologists and the researchers of language. These scholars have dealt with the problems of variation in different ways, which has given rise to formulation of various theories about linguisic variation from time to time.

John J. Guperz's name is associated with those scholars of linguistics who contributed to the field of linguistic variation extraordinarily. The methodology used by him for the classification of dialect differences has been outlined in one of his articles published in 1958. For carrying out his study, Gumperz selected a village called Khalapur as a place for his data collection. This village is located in the Saharanpur District of Utter Pradesh, India. Khalapur is surrounded by Khari Boli, a dialect of Western Hindi speaking belt. But, in Khalapur the villagers use Hindi fairly in their daily communication in various domains of their social life (Grierson, 1971, p. 27-28). Gumperz (1971), states that "Khalapur inhabitants are divided by profound differences in ritual status, wealth, political power, occupation and education, affecting every aspect of their daily life". (p.158). In his study, Gumperz (1958) found a direct relationship between the linguistic variation and caste membership. His study very clearly shows how social heterogeneity is reflected in the linguistic style of speakers.

Another important type of variation which has been most commonly noticed in American speech is related to the differing use of language in 'formal' and 'informal' situations. A kind of theory exploring this type of variation has been proposed by J.L. Fisher as early as in 1958. His theory was fully devoted to study the use of [y] variable in certain 'formal 'situations i.e. the pronunciation in words like- singing with [y] versus singin without [y]. Fischer (1958) observed that most Americans can confirm pronunciation like huntin found more commonly in 'informal' settings while the pronunciations like hunting with [ $\eta$ ] found in the most 'formal' situations. Here the terms 'formality' and 'informality' have been defined in terms of a particular society or a particular speech community. The style of speech used in formal versus informal situations are highly standardized and strictly differentiated. Ferguson (1959) has used the term 'diaglossia' for this type of linguistic variation and has described it in Arabic, Swiss, German, Haitian, French and Modern Greek.

Labov (1972) observes that "it is common for a language to have many alternate ways of saying "the same thing" (p.188). Some words like car and automobile, do have the same referents; others have two pronunciations like working (with [y] variant) and workin (without [y]variant). There are syntactic options such as Who is he talking to? Versus To whom he is talking? Or It's easy for him to talk versus For him to talk is easy (Labov, 1972, 188).

Labov (1972) also observed that it is the social structure of a speech community which has something to do with the change in the linguistic behavior of its speakers. Furthermore, Labov (1972) asserts that "internal structure pressures and the sociolinguistic pressures act systematic alternation in the mechanism of linguistic change" (Labov, 1972, P.181).

While studying relationship between language and society, Trudgill (1974) came up with the view that the linguistic variation to which he called 'fuzziness' is the direct result of social variation (Trudgill,1974).Trudgill (1974) admits that the social structure is reflected in the linguistic behavior of the speech community and social variation can produce linguistic variation.

Wardhaugh (1986) asserts that "when we look closely at any language, we will discover time and again that there is a considerable internal variation, and that speakers make constant use of many different possibilities offered to them" (Wardhaugh, 1986, p.5). Since each language exists in a number of different forms, the speakers make the use of these different varieties according to situations and no individual speaker speaks in the same way all the time. Wrdhaugh (1986) also admits that the dynamic model suggested by Bailey and Bickerton in 1973 emphasized the individual speech behavior to which they called the 'idiolect' whereas the others were concerned with group behavior to which they termed as the 'sociolect'. They theorized that one individual controls one idiolect of the language and the other controls another one, and these 'lects 'considerably vary from one another (Wardhaugh, 1986).

\section{Social and Linguistic Variables}

\section{Social Variables}

Almost all sociolinguistic studies and investigations are concerned with the ways wherein language varies according to the social context in which it is used. Languages also change according to the social group to which their speakers belong. As a matter of fact, no modern speech community offers to be a homogeneous one. In every speech community 
there is a social stratification or social heterogeneity. This social heterogeneity is reflected in the language use of its speakers and gives rise to speech variation among them. This is because of the fact that language and society are closely related. Therefore, it can be said that linguistic variation is closely related to social variation. This is also true to say that linguistic variation is due to the social variation. It is a well-established fact that for the linguistic variation certain social factors/ social variables such as religion, region (place of living/socioeconomic status), education, age and occupation are quite responsible. These social variables have been seen to modify the structure of language considerably and give rise to linguistic variation.

\section{Linguistic Variables}

The concept of linguistic variable is an outcome of research in The field of linguistic variation. Scholars have developed tools necessary for the identification of linguistic variation among different social groups. Hudson (1986), states that "the linguistic variables which sociolinguists have studied are those where the meaning remains constant but the form varies (Hudson, 1986, p.157)". For instance, two different forms 'cat' and 'pussy' are supposed to have same meaning and could therefore be considered as a linguistic variable. In the same way, the alternative pronunciation of 'house' with and without [h] can also be treated as an example of linguistic (variable Hudson, 1986).

Wardhaugh (1986) ,admits that" a linguistic variable is a linguistic item which has identifiable variants".( p.135). Wardhaugh (1986) further argues that the words like 'singing' and 'fishing' are sometimes pronounced by some speakers as 'singin' and 'fishin' respectively. The final sound in these words is called the linguistic variable [n]with its two variants as [y]in 'singing' and 'fishing' and [n] in 'singin' and 'fishin'. Another example of the linguistic variable is found in the words like 'car' and 'card'. These words are sometimes assigned the r less pronunciation by some speakers. Thus, in a way we can see the linguistic variable (r) with its two alternative forms or variants $[\boldsymbol{r}]$ and $\varnothing$ (pronounced as 'zero') (Wardhaugh, 1986).

\section{Methodology}

The present study follows the same pattern of the research methodology as adopted by other scholars of sociolinguistics while carrying out similar sociolinguistic investigations. The study is purely data oriented, and the entire data has been collected from a sample of 105 subjects/respondents, who are the native speakers of the Kashmiri language. The subjects/respondents have been selected in such a way that they were the true representatives of the whole Kashmiri speech community. It has also been made sure that they belong to different social levels, groups, and sects of the society.

\section{A. Objectives of the Study}

The main objective of this study is to investigate as to how the social stratification or the social heterogeneity of the Kashmiri Speech Community is reflected in the linguistic behavior of its speakers and gives rise to variation among them in the use of their language at the level of phonology and lexicon in accordance with certain social variables. viza-viz religion, region (place of living/socioeconomic status) education, age and occupation.

\section{B. Hypotheses}

Keeping in view the main objectives of the present study and exploratory discussion with the members of the speech community under investigation, the following hypotheses have been formulated to be tested and verified.

i) As the structure of the Kashmiri language varies considerably, at various social levels of the Kashmiri speech community. The reason for this linguistic variability has to be explained in accordance with the social variation. This is because of the fact that linguistic variables are correlated with the social variables as language and society are closely related to each other.

ii) To investigate the linguistic variability of Kashmiri language and to relate it to social heterogeneity of the Kashmiri speech community, and to see how this social variation of the Kashmiri speech community is reflected in the structure of the Kashmiri language at various levels of its organization.

\section{Data collection}

The data for the present study has been collected by various methods, such as the distribution of the questionnaire, conducting interviews, and the investigator's direct involvement in some conversations with various members of the speech community. As far as the places of data collection are concerned, they have been selected keeping in view the concentration of Kashmiri speakers belonging to different social groups. These places mainly include: entertainment parks, gardens, tourist spots, hostels, schools, colleges, bus stops, markets, paddy fields, orchards, government offices, hospitals, exhibition grounds, and other similar places. In order to get the data as natural as possible, the investigator also visited many villages, towns, urban centers, and some other common meeting places, where the people from different social backgrounds of the said speech community were easily available and had oral communication related to the matters of day-to-day life. The investigator also visited the different occupational groups of the speech community. The speakers belonging to different social groups, viz., farmers, office goers (teachers, doctors, lawyers, businessmen etc.), fisherman/ boatmen and businessmen have been approached and were asked some questions related to their respective occupations/professions and their responses were recorded in natural way.

\section{Editing of the Data}


It may be pointed out that the entire mass of the data collected was not useful for the purpose of the present study. Therefore, the irrelevant, weak, unwanted and doubtful portions of the data were weeded out and eliminated. In the process of editing, the weaknesses found in the data were rectified and made useful for the purpose.

\section{Data Analysis}

After the completion of editing the data, the resultant and the desired portion was analyzed. This process involved the verification of the proposed hypotheses of the present investigation to arrive at the right conclusion and desired results. Finally, the interpretation was done, i.e. the resultant data was tabulated. The tabulation of data facilitated the understanding of data and simplified its process of study.

\section{RESULTS AND ANALYSIS}

\section{A. Social Structure of the Kashmiri Speech Community}

The state of Jammu and Kashmir is the home to various sects of people. The people of this state belong to different social groups. Technically speaking, there is a social stratification or we may call it social heterogeneity in the Kashmiri Speech community. Kashmiri speakers are mainly concentrated in state of Jammu and Kashmir; particularly in the valley of Kashmir. Kashmiri is the principal regional and dominant majority language of the valley of Kashmir. It is predominantly spoken as the mother tongue by the entire population of the valley. Although due to the disturbed condition of the state quite a good number of Kashmiri speakers are settled outside the valley in different states and union territories of India, they maintain their language i.e. Kashmiri.

Kashmiri speech community is predominantly a Muslim majority community. Second to Muslims are Hindus, constituting a microscopic population in the valley of Kashmir. Although the people of these two faiths share the same language as their mother tongue and live together in a very congenial and friendly set of circumstances, but they vary considerably from social, cultural and religious points of view. As a matter of fact, the common surnames among the Muslims and Hindus like Bhat, Raina, Pandit, Koul, Shah, Bakhshi etc. are not even going to bridge the socio-cultural gap between these two communities who have been living together for centuries. Most of the Muslims are agriculturalists and the majority of Hindus belong predominantly to service and office going class. Thus the variable religion divides the speech community into two groups of speaker's viz., Hindu Kashmiri speakers and Muslim Kashmir speakers

On the basis of region (place of living/ socioeconomic status), the Kashmiri speech community comprises two main groups of speakers i.e. the urban Kashmiri speakers and the rural Kashmiri speakers. The Kashmiri speakers living in the city of Srinagar and in its vicinity are the urban Kashmiri speakers and those who live in the rest parts of the valley other than the city of Srinagar are considered as rural Kashmiri speakers. The rural Kashmiri speakers are mostly the agriculturalists. They are also by and large disadvantaged in the field of education as compared to their urban counterparts. The urban Kashmiri speakers on the other hand, constitute the business class, the educated elite and the less advantaged labor. There are of course rich and educated agriculturalists in rural areas too, but their number is quite low. There are also a considerable number of rural people who have migrated towards the urban centers where they found good educational and other facilities for themselves as well as for their children.

As a matter of fact, every individual of the society doesn't have equal opportunity to get education. Therefore, some are literates and others have grown as illiterates. There is no denying the fact that the highly educated and literate class of the Kashmiri society hails from the urban areas and the rural Kashmiri speakers have been lagging behind in the field of education. The reason for this little percentage of literacy among the rural Kashmiri speakers is their rural and agricultural background. As they are busy in looking after their agricultural lands, they pay little attention to education. Education is thus in a way another important social variable on the basis of which the entire speech community has been divided into two groups of speakers viz. literate speakers (E1) and illiterate speakers (E2). Similarly, on the basis of variable age we have two age groups A1 (15-50 years) and A2 (50 years and above).

In order to make their living and earn their bread, the people of the Kashmiri society like other living societies of the world have entered different occupations and professions. The main occupational groups of the Kashmiri speech community are: farmers, office goers (teachers, doctors and lawyers), boatmen/fishermen and businessmen/traders.

\section{B. Linguistic Variation among the Kashmiri Speech Community}

Language variation is the direct outcome of social variation because language and society are closely related to each other. The social heterogeneity of Kashmiri speech community is prominently reflected in the linguistic behavior of Kashmiri speakers and leads them to vary considerably in the use of their language at various levels of linguistics. The resultant linguistic variables are the indicators of one's social identity. The variation in language among the Kashmiri speech community at the level of phonology and lexicon has been found in accordance with social variables viz., religion, region (place of living/socioeconomic status), education, age and occupation/profession. This linguistic variation among the Kashmiri speakers is of course due to the social variation of the Kashmiri speech community. Individuals of two different social groups have not been seen to follow the same pattern and same structure of the language. Different speakers of the same language have been seen to express same meanings using different forms. They are bound to vary in their linguistic usage as they differ socially.

Phonological Variation among Kashmiri Speakers. 
The social heterogeneity of the Kashmiri speech community is very prominently reflected in the speech of its speakers which shows variations of various types. These variations have been observed and analyzed in terms of differences in the use of consonants, vowels, semi-vowels, and vowel sequences correlating with certain social variables in their society. Given below are some phonological variables with their corresponding social variables of the Kashmiri speech community.

\section{Phonological Variation due to Religious Differences}

\subsection{Consonants}

Religion is an important social factor which divides the Kashmiri Speech Community into two main groups of speakers, viz., The Hindu Kashmiri Speakers and the Muslim Kashmiri Speakers. The variety of Kashmiri spoken by Hindu Kashmiris may be termed as the Hindu Kashmiri (HK), and the variety of the same language spoken by their Muslim counterparts may be called the Muslim Kashmiri (MK). These two groups of speakers of the same language have been seen to vary considerably in the use of the sound system of the said language. Grierson (1919) states that the main reason behind this variation is that the form of Kashmiri spoken by the Hindu Kashmiri Speakers is filled with the vocabulary items borrowed from the Sanskrit sources, and the variety of Kashmiri spoken by the Muslim Kashmiri speakers is mostly filled with the lexicon of the Persian and Arabic origin. These two verities were later called by Kachru (1969) 'Sankritized' and 'Persianized' Kashmiri respectively. (Kachru, 1969).

\subsubsection{Variation of voiced alveolar trill $[\mathrm{r}]$ and voiced unaspirated retroflex stop [d]}

The variation of $[\mathrm{r}]$ and $[\mathrm{d}]$ reflects religious differences among the speakers of the Kashmiri speech community. The Kashmiri equivalents for 'rat' and 'horse' are pronounced by the Hindu Kashmiri speakers as gagur and gur respectively, whereas the Muslim speakers (rural Muslim speakers only) of the same language pronounce these words as gagud and gud respectively. Thus, the final sound in these words may be termed as linguistic variable (r) with its two variants [r] as in gagur 'rat' and gur 'horse' and [d] as in gagud 'rat' and gud 'horse'. It may be pointed out that Hidu Kashmiri speakers irrespective of their region (urban or rural) of their living and socioeconomic status use the urban variety of Kashmiri. Following table shows more examples of this type of variation.

TABLE 2.1:

VARIATION OF [R] AND [D] AMONG THE HINDU AND MUSLIM KASHMIRI SPEAKERS

\begin{tabular}{|c|c|c|}
\hline Hindu Kashmiri Speakers (HK) & Muslim Kashmiri Speakers (MK) & Gloss \\
\hline /nər/ & / nəd/ & 'arm’ \\
\hline / šUr/ & / šUd/ & 'child' \\
\hline /kokUr/ & / kokUd/ & 'cock’ \\
\hline /zor/ & / zod/ & 'deaf' \\
\hline / hagUr/ & / hagUd/ & 'wooden cart' \\
\hline / bro:r/ & / bro:d/ & 'cat' \\
\hline / ku::r/ & / ku:d/ & 'daughter' \\
\hline / tsər / & /tsəd/ & 'sparrow' \\
\hline /ger / & /gad / & 'watch' \\
\hline / lu:r / & /lu:d/ & 'stick' \\
\hline / nə:r / & / nə:d/ & ‘jug’ \\
\hline / kə:r/ & / kə:d / & 'neck' \\
\hline / və:r / & /vo:d / & 'kitchen garden' \\
\hline / kor / & /kod / & 'bangle' \\
\hline / čo:r / & / čho:d / & 'dumb' \\
\hline / də:r / & / də:d / & 'beard' \\
\hline / pə:r / & / pə:d / & 'hut' \\
\hline / gə:r / & / ga:d / & 'fish' \\
\hline / dor / & / dod / & 'hard' \\
\hline / lə:r / & / lə:d/ & 'cucumber' \\
\hline
\end{tabular}

\subsubsection{Variation due to the deletion of [ət], [əts] and [əč]}

It has been noticed that in some of the loanwords of the Perso-Arabic sources, the final sounds like [ət], [əts] and [əč] which are optionally deleted in the speech of Muslim Kashmiri speakers (MK), are somehow retained in the speech of their Hindu counterparts (HK). Some examples justifying this fact are given below:

TABLE 2.2

VARIATION DUE TO DELETION AND RETENTION OF [ӘT] AND [ӘTS] AMONG HINDU AND MUSLIM KASHMIRI SPEAKERS.

\begin{tabular}{|l|l|l|}
\hline Hindu Kashmiri Speakers (HK) & Muslim Kashmiri Speakers (MK) & Gloss \\
\hline / sakhət / & /sakh / & 'hard' \\
/ makəts / & / makh / & 'axe' \\
/ vakhət / & / vakh / & 'time' \\
/ ta:khəč / & / ta:kh / shelf( of a window)' \\
\hline
\end{tabular}

\subsection{Vowels}

\subsubsection{Variation of mid back rounded long vowel [o: ] and low central long vowel [ a:]}

One of the most striking variations due to the religious differences among the speakers of the Kashmiri speech community has been found to be the variation of mid back rounded long vowel [o: ] and low central long vowel [ a:]. In their use of past participle and past perfect tense forms, a set of verbs in the speech of Muslim Kashmiri speakers (MK) 
has different phonological equivalents from their Hindu counterparts (HK). These variations have been observed when the Kashmiri speakers talk about or refer only to the male individuals and masculine object. Some examples of showing this type of variation are listed below:

TABLE 2.3

VARIATION OF [O:] AND [A:] AMONG THE HINDU AND THE MUSLIM KASHMIRI SPEAKERS

\begin{tabular}{|l|l|l|}
\hline Hindu Kashmiri Speakers (HK) & Muslim Kashmiri Speakers (MK) & Gloss \\
\hline / dra:mUt / & / ðro:mUt & 'had gone' \\
/ tsa:mUt / & / tso:mUt / & 'had entered' \\
/ a:mUt / & / o:mUt / & 'had come' \\
/ ra:mUt / & / ro:mUt / 'had lost' \\
/ ha:umUt / & / ho:umUt / & 'had shown' \\
/ tra:umUt / & / tro:umUt / & 'dropped/put/delivered' \\
\hline
\end{tabular}

\subsubsection{Variation of mid central unrounded long vowel [ə:] and low central long vowel [a:]}

Another similar variation among the speakers of the same speech community on the basis of religious differences pertaining to the same set of grammatical categories has been noticed in the use of mid central unrounded long vowel [ə:] in the speech of Muslim speakers (MK) with its alternative form, i.e. the low central long vowel [a:] in the speech of Hindu speakers (HK). On the contrary, these variations have been noticed to come into being when both the categories of the speakers refer to or talk only about the female individuals and feminine objects. Some examples of this type of variation are given below:

TABLE 2.4

VARIATION OF [ə: ] AND [A:]AMONG THE HINDU AND THE MUSLIM KASHMIRI SPEAKERS

\begin{tabular}{|l|l|l|}
\hline Hindu Kashmiri Speakers (HK) & Muslim Kashmiri Speakers (MK) & Gloss \\
\hline / ðra:mits / & / ðrə:mits / & ' had gone' \\
/ tsa:mits / & / tsə:mits / & ' had entered' \\
/ a:mits / & / ə:mits / ' had come' \\
/ ra:mits / & / rə:mits / & 'had lost' \\
/ ha:mits / & / hə:mits / & 'shown' \\
/ tra:mits / & / trə:mits / & 'dropped/put/delivered' \\
\hline
\end{tabular}

\subsubsection{Variation of low central short vowel [a] and mid front unrounded short vowel [e]}

While using the past tense forms of certain verbs, low central short vowel [a] in the speech of Hindu Kashmiri speakers (HK) is replaced by mid front unrounded short vowel [e] in the speech of their Muslim counterparts (MK). Following table shows the examples of this type of variation.

TABLE 2.5

VARIATION OF [A] AND [E] AMONG THE HINDU AND THE MUSLIM KASHMIRI SPEAKERS

\begin{tabular}{|c|c|c|}
\hline Hindu Kashmiri Speakers (HK) & Muslim Kashmiri Speakers (MK) & Gloss \\
\hline / ðopmas / & / ðopmes / & 'I told him/her' \\
\hline / ðopnas / & / ðopnes / & 'he/she told him/her' \\
\hline / ðyutnas / & / dyutnes / & 'he/she gave it to him/her' \\
\hline / ðyutmas / & / ðyutmes / & 'I gave it to him/her' \\
\hline / hyotmas / & / hyotmes / & 'I bought it for him/her' \\
\hline /hyotmas / & / hyotmes / & 'I took it from him/her' \\
\hline / hyotnas / & / hyotnes/ & ' he/she bought for him/her \\
\hline / rotmas / & / rotmes / & 'I had it from him/her' \\
\hline / neumas / & / nuemes / & 'I took it from him/her' \\
\hline / neumas / & / neumes / & 'I gave it to him/her' \\
\hline / neunas / & / neunes / & 'he/she took it from him/her' \\
\hline / neunas / & / neunes / & 'he/she gave it to him/her' \\
\hline / lyokhmas / & / lyokhmes / & 'I wrote to him/her' \\
\hline / lyokhnas / & / lyokhnes / & 'he/she wrote to him/her' \\
\hline / vUčhmas / & / vUčhmes/ & 'I saw it with him/her' \\
\hline / vUčhnas / & / vUčhnes / & 'he/she him/her' \\
\hline / čhavan / & /čhevan / & 'drinking/drinks' \\
\hline
\end{tabular}

\section{Phonological Variation due to Difference in Educational Level}

It has been noticed that the literate (E1) speakers of the speech community under study pronounce a large number of words quite differently from their illiterate (E2) counterparts. They have been seen to show great affinity towards the standard variety of Kashmiri. The main reason behind this variation is that a majority of the speakers from literate (E1) group are office goers and have more opportunities to remain in contact with the speakers of the standard variety of Kashmiri. As a matter of fact, the speakers of the illiterate (E2) group have been found to use the non-standard variety of Kashmiri in their day-to-day conversation.

Vowels and Semi-vowels

2.1 Variation in the use of high front unrounded short vowel [i] and voiced palatal frictionless continuant semivowel $[y]$ 
The Kashmiri equivalents for 'wait' and 'arrangement' are pronounced as intiza:r and intiza:m respectively by the speakers belonging to literate (E1) group of Kashmiri speakers. The speakers of the illiterate (E2) group pronounce the same words as yintiza:r 'leader' and yintiza:m 'arrangement'. On the basis of such examples, it can be stated that some words of the Perso-Arabic origin beginning with high front unrounded short vowel [i] used by the literate (E1) speakers are prefixed by the frictionless continuant semi-vowel [y] by illiterate (E2) group of speakers in their speech. Other examples of this type of variation are tabulated as below:

TABLE 2. 6

VARIATION OF [ I] AND [Y] AMONG THE LITERATE (E1) AND ILLITERATE KASHMIRI SPEAKERS

\begin{tabular}{|c|c|c|}
\hline Literate Kashmiri Speakers (E1) & Illiterate Kashmiri Speakers (E2) & Gloss \\
\hline / inka:r/ & / yinka:r / & 'refusal' \\
\hline / ibtiða: / & / yibtiða: / & 'beginning' \\
\hline / intiha: / & / yintiha: / & 'extreme' \\
\hline / iltija: / & / yiltija: / & 'request' \\
\hline / izha:r / & / yizha:r / & 'expression’ \\
\hline / isla: / & / yisla: / & 'reform/shave' \\
\hline / idra:r / & / yidra:r / & 'urine' \\
\hline / itla: / & / yitla: / & 'information' \\
\hline / intika:m / & / yintika:m / & 'revenge' \\
\hline / inkila:b / & / yinkila:b / & 'revolution' \\
\hline /ima:m / & /yima:m / & 'religious leader \\
\hline / istiфa: / & / yistiфa: / & 'resignation' \\
\hline / ikhtila: $\phi$ / & / yikhtila:ф / & 'difference/dispute' \\
\hline / iфtiya:r / & / yiфtiya:r / & 'opening the fast' \\
\hline / inša:ala: / & / yinša:ala: / & 'if God wishes' \\
\hline / imtiha:n & / yimtiha:n / & 'examination ' \\
\hline
\end{tabular}

\subsection{Variation of mid front unrounded short vowel [e] and voiced palatal frictionless continuant semivowel [y]}

A similar type of phonological variation due to difference in educational level has been found due to varied use of mid front unrounded short vowel [e] and voiced palatal frictionless continuant semivowel [y]. Quite a good number of words of Perso-Arabic origin beginning with mid front short vowel [e] in the speech of the literate (E1) speakers of Kashmiri have been found to be prefixed with voiced palatal frictionless continuant semi-vowel [y] by the illiterate (E2) speakers of the same language. Some examples depicting this type of variation are given below:

TABLE 2.7

VARIATION OF [E] AND [Y] AMONG THE LITERATE (E1) AND ILLITERATE [E2] KASHMIRI SPEAKERS

\begin{tabular}{|l|l|l|}
\hline Literate Kashmiri Speakers (E1) & Illiterate Kashmiri Speakers (E2) & Gloss \\
\hline / ela:j / & / yela:j / & 'treatment' \\
/ ekhla:k / & / yekhla:k / behavior/manners' \\
/ ehsa:n / & / yehsa:n / & 'obligation' \\
/ ela:n / & / yela:n / announcement' \\
/ ema:m / & / yena;m / & ' award' \\
/ ekhteya:r / & / yekhteya:r / & 'option' \\
/ eteфa:k / & / yeteфa:k / 'agreement' \\
/ ekra:r / & / yekra:r / & 'acceptance' \\
\hline
\end{tabular}

\section{Phonological Variation due to Regional and Socioeconomic differences}

Among the Kashmiri speech community there are regional differences and for that matter the urban (UK) and rural speakers (RK) show considerable variations in their speech at the level of phonology. Some of the phonological variables commonly found among the Kashmiri speakers belonging to two different regions are discussed below:

\subsection{Vowels}

3.1.1 Variation of high back rounded short vowel [U] and mid central unrounded short vowel [ $i$ ]

It has been observed that the high back rounded short vowel [U] in some monosyllabic and in the first syllable of some disyllabic words in the speech of urban Kashmiri speakers (UK) is replaced by mid central unrounded short vowel [i] in the speech of rural Kashmiri speakers (RK), giving rise to phonological variation among the said speech community at a very large scale. Examples showing this type of variation are shown below:

TABLE 2.8

VARIATION OF [U] AND [ə] AMONG THE URBAN AND RURAL KASHMIRI SPEAKERS

\begin{tabular}{|l|l|l|}
\hline Urban Kashmiri Speakers (UK) & Rural Kashmiri Speakers (RK) & Gloss \\
\hline / bUd / & / bid / & 'old lady' \\
/ bUdi/ & / bidi / & 'old man' \\
/ vUčh / & / vičh / & 'see/saw' \\
/ lučhi / & / ličhi / & 'thin' \\
\hline
\end{tabular}

3.1.2 Variation of low central long vowel [a:] and low central short vowel [a]

Another remarkable variation observed at the phonological level among the Kashmiri speakers on the basis of region is the use of low central long vowel [a:] in the speech of urban speakers (UK) versus the use of low central short vowel [a] in the speech of their rural(RK) counterparts. This lengthening of low central long vowel [a:] in simple present and 
present progressive tense forms of verbs is a typical and striking feature found in the speech of urban Kashmiri speakers (UK) which clearly differentiates them from the rural speakers (RK) of the same language with their typical use of low central short vowel [a] in the same set of the verb forms. For example, the words (verbs) karan 'doing/does' and khevan 'eating/eats' pronounced so by the rural Kashmiri speakers(RK) are pronounced as kara:n 'doing/does' and kheva:n 'eating/eats respectively by their urban counterparts(UK). This alternation/variation in the use of language among urban 9UK) and rural (RK) Kashmiri speakers is so remarkable and noticeable that even a non-Kashmiri is able to observe it. Some more examples showing this type of phonological variation are tabulated below:

TABLE 2.9

VARIATION [A:] AND [A] AMONG THE URBAN AND RURAL KASHMIRI SPEAKERS

\begin{tabular}{|l|l|l|}
\hline Urban Kashmiri Speakers (UK) & Rural Kashmiri Speakers (RK) & Gloss \\
\hline / gatsha:n / & / gatshan / & 'going / goes / \\
/ dava:n / & /davan / 'running/runs' \\
/ yiva:n / & / yivan / & 'coming / comes' \\
/ dUva:n & / dUvan / & 'sweeping/ sweeps' \\
/ roza:n / & / rozan & 'living/ lives' \\
/ heva:n / & / hevan / & 'buying/buy' \\
/ ana:n / & / anan / & 'bringing / brings \\
/ vaða:n / & / vaðn / & 'weeping /weeps' \\
/ čava:n / & / čavan / & 'drinking / drinks' \\
/ sUva:n / & / sUvan/ & 'stitching / stitches' \\
/ khana:n / & / khanan / & 'digging/ digs' \\
/ zana:n / & / zanan / & 'knowing /knows / \\
/ tshãda:n / & / tshãdan / & 'looking /looks for' \\
\hline
\end{tabular}

\subsubsection{Variation of mid back rounded long vowel [o:] and low central long vowel [a:]}

A most typical type of variation due to the regional differences among the urban (UK) and the rural (RK) speakers of the Kashmiri speech community has been found to be the variation of mid back rounded long vowel [o:] and low central long vowel [ a:]. In their use of past participle and past perfect tense forms, a set of verbs in the speech of urban Kashmiri speakers (UK) have different phonological equivalents in the speech of their rural counterparts (RK). These variations have been observed when these speakers exclusively refer to or talk about the male individuals and famine ojects. Some examples showing this type of variation are listed below:

TABLE 2.10

VARIATION OF [O:] AND [A:] AMONG THE URBAN AND RURAL KASHMIRI SPEAKERS

\begin{tabular}{|c|c|c|}
\hline Urban Kashmiri Speakers (UK) & Rural Kashmiri Speakers (RK) & Gloss \\
\hline / ðra:mUt & / ðro:mUt / & 'had left/gone' \\
\hline / tsa:mUt & / tso:mUt / & 'had entered' \\
\hline / a:mUt / & / o:mUt / & 'had come' \\
\hline / ra:mUt / & /ro:mUt / & 'had lost' \\
\hline / ha:umUt / & / ho:umUt / & 'had shown' \\
\hline / tra:umUt / & / tro:umUt & 'dropped/put/delivered' \\
\hline
\end{tabular}

\subsection{Variation of mid central unrounded long vowel [ə:] and low central long vowel [a:]}

Another similar variation among the speakers of the same speech community on the basis of regional differences pertaining to the same set of grammatical categories has been noticed in the use of mid central unrounded long vowel [ə:] in the speech of rural speakers (RK) with its alternative form i.e. the low central long vowel [a:] in the speech of their urban counterparts (UK). On the contrary these variations have been noticed to come into being when both the categories of the speakers refer to or talk only about the female subjects and famine objects. Some examples of this type of variation are given below:

TABLE 2.11

VARIATION OF [ə:] AND [A:] AMONG THE URBAN (UK) AND RURAL KASHMIRI SPEAKERS (RK)

\begin{tabular}{|l|l|l|}
\hline Urban Kashmiri Speakers (UK) & Rural Kashmiri Speakers (RK) & Gloss \\
\hline / ðra:mits / & / ðrə:mits / & ' had gone' \\
/ tsa:mits / & /tsə:mits / ' had entered' \\
/ a:mits / & / ə:mits / & ' had come' \\
/ ra:mits / & / rə:mits / & 'had lost' \\
/ ha:mits / & / hə:mits / & 'shown' \\
/ tra:mits / & / trə:mits / & 'dropped/put/delivered' \\
\hline
\end{tabular}

\subsubsection{Variation of low central short vowel [a] and mid front unrounded short vowel [e]}

It has been found that during the use of certain past tense verb forms, the speech of Urban Kashmiri speakers (UK), with the use of low central short vowel [a] is clearly differentiated from the speech of their rural counterparts (RK) with their use of mid front unrounded short vowel [e] in their speech. Following table shows the examples of this type of variation. 
TABLE 2.12

VARIATION OF [A] AND [E] AMONG THE URBAN AND RURAL KASHMIRI SPEAKERS

\begin{tabular}{|c|c|c|}
\hline Urban Kashmiri Speakers (UK) & Rural Kashmiri Speakers (RK) & Gloss \\
\hline / ðopmas / & / ðopmes / & 'I told him/her' \\
\hline / ðopnas / & / ðopnes / & 'he/she told him/her' \\
\hline / ðyutnas / & / ðyutnes / & 'he/she gave it to him/her' \\
\hline / ðyutmas / & / dyutmes / & 'I gave it to him/her' \\
\hline / hyotmas / & / hyotmes / & 'I bought it for him/her' \\
\hline /hyotmas / & / hyotmes / & ' I took it from him/her' \\
\hline / hyotnas / & / hyotnes/ & ' he/she bought for him/her \\
\hline / rotmas / & / rotmes / & 'I had it from him/her' \\
\hline / neumas / & / nuemes / & 'I took it from him/her' \\
\hline / neumas / & / neumes / & 'I gave it to him/her' \\
\hline / neunas / & / neunes / & 'he/she took it from him/her' \\
\hline / neunas / & / neunes / & 'he/she gave it to him/her' \\
\hline / lyokhmas / & / lyokhmes / & 'I wrote to him/her' \\
\hline / lyokhnas / & / lyokhnes / & 'he/she wrote to him/her' \\
\hline / vUčhmas / & / vUčhmes/ & 'I saw it with him/her' \\
\hline / vUčhnas / & / vUčhnes / & 'he/she him/her' \\
\hline / čhavan / & /čhevan / & 'drinking/drinks' \\
\hline
\end{tabular}

\subsection{Consonants}

\section{Variation of voiced alveolar trill $[\mathrm{r}]$ and voiced unaspirated retroflex stop [d]}

The frequent use of $[\mathrm{r}]$ in the speech of urban Kashmiri speakers (UK) in place of [d] in the speech of their rural counterparts (RK) has been considerably noticed. For example, the words kokUr 'cock' and ku:r 'daughter/girl' pronounced so by urban Kashmiri speakers (irrespective of their religious background i.e..both Hindu and Muslim Kashmir speakers) ,are pronounced by as kokUd 'cock' and $\boldsymbol{k u}$ :d 'daughter/girl' by their rural counterparts (only Muslim rural Kashmiri speakers. . This variation of [r] and [d] in the speech of rural (RK) and urban speakers (UK) of the Kashmiri language has been noticed at the medial and final positions of a large number of words. The examples supporting this type of variation are tabulated below:

TABLE 2.13

VARIATION OF [R] AND [D] AMONG THE URBAN AND RURAL KASHMIRI SPEAKERS

\begin{tabular}{|c|c|c|}
\hline Urban Kashmiri Speakers (UK) & Rural Kashmir Speakers (RK) & Gloss \\
\hline / rabar / & / rabad / & 'rubber' \\
\hline / margUza:r / & / madgUza:r / & 'grave yard' \\
\hline /marið / & / madið / & 'man' \\
\hline / šUr / & / šUd / & 'child' \\
\hline / jagri / & / jagdi / & 'quarrel' \\
\hline / kãngir / & / kãngid / & 'fire pot' \\
\hline / zor / & / zod / & 'deaf' \\
\hline / zər / & / zod / & 'deaf(fem.)' \\
\hline / čho:r / & / čho:d / & 'dumb' \\
\hline / čhə:r / & / čhə:d / & 'dumb (fem.) \\
\hline / lar / & / lad / & 'lie in' \\
\hline / parði / & / padði / & 'curtain' \\
\hline / biniri / & / binidi / & 'bangles' \\
\hline / kor / & / kod / & 'a big bangle' \\
\hline / trakUr / & / trakUd / & 'swift' \\
\hline / trakir / & / trakid / & 'tool for weighing' \\
\hline
\end{tabular}

\section{Lexical Variation}

The social heterogeneity of the Kashmiri speech community has also given rise to variation in the use of language among its speakers at its level of lexicon to a large extent. There is a considerable stock of lexical items found in the speech of a particular group of Kashmiri speakers which is either totally missing in the speech of another group of speakers, or that group has developed an alternative set of lexical items conveying the same meaning. In this study an attempt has been made to examine the lexical variation among the Kashmiri speakers in accordance with four social factors viz.-a-viz. religion, age, education and occupation/profession.

\section{Lexical Variation due to the difference in Religion}

It has been observed that there are a good number of lexical items found in the speech of Hindu Kashmiri speakers (HK) which are not found in the speech of Muslim Kashmiri speakers (MK), for which they have developed an alternative set of the lexical items conveying the same meaning (different forms with the same meaning). For example, the Kashmiri equivalents for 'water' and 'cooked meat' in the Hindu's speech (HK) are pon $\boldsymbol{Y}$ and neni respectively, and the Kashmiri equivalents for these two words- 'water; and 'cooked meat' in the variety of speech spoken by Muslim Kashmiris (MK) are $\boldsymbol{a}: \boldsymbol{b}$ and $\boldsymbol{n a}: t ̦ i$ respectively. The other examples depicting this type of variation are tabulated as below: 
TABLE 3.1

LEXICAL VARIATION DUE TO THE DIFFERENCES IN RELIGION

\begin{tabular}{|c|c|c|}
\hline Hindu Kashmiri Speakers (HK) & Muslim Kashmiri Speakers (MK) & Gloss \\
\hline / a: ša: / & / Ume:ð / & 'hope' \\
\hline / bohgUn / & / potYli / & 'cooking vessel' \\
\hline / sorig / & / jana $\theta$ / & 'heaven/paradise' \\
\hline / narUkh / & / jahnam / & 'hell' \\
\hline / zal / & / pi ša:b / & 'urine' \\
\hline / ãg / & / hisi / & 'part' \\
\hline / š̃̃:ti: / & / amUn / & 'peace' \\
\hline / məðrer / & / khãd / & 'sugar' \\
\hline / havan / & / niya:z / & 'donation' \\
\hline / mombatY / & / šama / & 'candle' \\
\hline / šari:r / & / jisim / & 'body’ \\
\hline / mogalčai: / & / kəhvi / & 'coffee' \\
\hline / amrit / & / a:bihaya:t / & 'elixir', \\
\hline / ðaram / & / ði:n / & 'religion' \\
\hline / praba $\theta /$ & / sahar / & 'dawn' \\
\hline / sapUn / & / kha:b / & 'dream' \\
\hline / bra $\theta a:$ / & / khãvãð / & 'husband' \\
\hline / go: r / & / Usta:ð / & 'teacher' \\
\hline / login / & / nika:h / & 'marriage ceremony/bond' \\
\hline / šUkirva:r / & / jUma / & 'Friday' \\
\hline / šara:n / & / gosUl / & 'bath' \\
\hline / šru:ts / & / pa:kh / & 'pious/pure' \\
\hline / pi: țy / & / sonðu:k / & 'box' \\
\hline / pu:rer / & / barka $\theta$ / & 'blessing' \\
\hline / siri / & / a:фta:b / & 'sun’ \\
\hline / kru:d / & / šarara $\theta$ / & 'anger' \\
\hline / samkhUn / & / tə:zya $\theta$ / & 'condolence visit' \\
\hline / mu:rti / & / potUl / & ‘idol’ \\
\hline / vəhrəvo:d / & / zahðoh / & 'birth day' \\
\hline / pa:p / & /gonah / & 'sin' \\
\hline / kho:s / & / pyali / & 'cup' \\
\hline / iba:ða $\theta$ / & /pu:za: / & 'worship' \\
\hline
\end{tabular}

\section{Lexical variation due to the difference in Age}

It is a linguistic fact that languages do change and vary with age. During the course of time many new words are added to lexicon of a language because of new inventions and discoveries. This phenomenon enriches the vocabulary build of that particular language. It is also true to say that at the same time; many words are deleted and eliminated from the existing lexicon of a particular language with the passage of time. Thus, words keep on coming and going with age. This principle is quite applicable to the Kashmiri lexicon to a considerable extent as well. The two groups of Kashmiri speakers viz., (A1) i.e. the speakers falling under the age of 15-50 years and (A2), those having age from 60 years and above have been seen to show notable and considerable variations in the use of their language at the level of lexicon. It has been observed that the speech (lexicon) of speakers belonging to age group A1 (15-50 years) is characterized by modern and technical terminologies. The enrichment of their speech and lexicon is a direct consequence of borrowing from other languages with which these speakers are in direct contact. Moreover, their exposure to the latest developments and the current affairs has also been an edge for the enrichment of their lexicon. On the contrary, their counterparts, i.e. speakers belonging to age group A2 (50 years and above) are less advantaged in terms of their exposure to the current affairs and the latest development, ad happenings. This has resulted in the development of a very limited range of lexical stock in their speech. The examples showing variation among the Kashmiri speakers with regard to age are tabulated below: 
TABLE 3.2

LEXICAL VARIATIONS DUE TO THE DIFFERENCES IN AGE

\begin{tabular}{|c|c|c|}
\hline $\begin{array}{l}\text { A1(Kashmiri Speakers wsith age of } 15-50 \\
\text { years) }\end{array}$ & $\begin{array}{l}\text { A2 (Kashmiri Speakers with age of } 50 \text { years } \\
\text { and above) }\end{array}$ & Gloss \\
\hline / čhapinY / & /na:lə:nY / & 'sleeper' \\
\hline / bu: țh / & / khorba:n / & 'shoe' \\
\hline / țrouzar / & / yeza:r / & ' trouser' \\
\hline / jaha:zi / & / vatsipreng / & 'airplane' \\
\hline / mə:1/ & $/ \operatorname{ragba} \theta /$ & 'appetite' \\
\hline / kičan / & / da:ni kUț h / & 'kitchen' \\
\hline / paiðal / & / vokhlY / & 'walking on foot' \\
\hline / galti: / & / atUd / & 'mistake' \\
\hline / kõnju:s / & / kõd / & 'miser' \\
\hline /dasta:r / & / malməlY / & 'turban, \\
\hline / ki:ma $\theta$ / & / nerakh / & 'price' \\
\hline / be:g / & / ț he:li / & 'bag' \\
\hline / ðor / & / paiða:r / & 'durable' \\
\hline / piša:b / & / iðra:r / & 'urine' \\
\hline / moț h / & / čhrõg / & 'handful' \\
\hline / tsi:rY pahan / & / aðibə:gY / & 'later on' \\
\hline / kəmiz / & / kurtanY / & 'shirt' \\
\hline
\end{tabular}

\section{Lexical Variation due the difference in Education.}

It has been found that the literate (E1) and illiterate (E2) Kashmiri speakers show remarkable variations in their speech at the level of lexicon. Like the speakers of the age group A1 (15-50 years), the speech of literate (E1) group of Kashmiri speakers is mostly filled with modern, scientific, and technical terminologies as compared to their illiterate (E2) counterparts. They (E1) have been found to show a great tendency to be updated with the current affairs and the latest happenings related to the modern inventions. With the result, they borrow a considerable number of vocabulary items from other languages especially English. This process enables them to enrich their word build with modern and technical vocabulary items. Some examples showing this type of variation are listed as below:

TABLE 3.3

LEXICAL VARIATION DUE THE DIFFERENCE IN EDUCATION.

\begin{tabular}{|c|c|c|}
\hline Literate Kashmir Speakers (E1) & Illiterate Kashmiri Speakers (E2) & Gloss \\
\hline / kUrtanY / & / kəmi:z / & 'shirt' \\
\hline / kamri / & / kUț h / & 'room' \\
\hline / rištiða:r / & / ə: šna:o / & 'relative' \\
\hline / pə:ja:mi / & / yeza:r / & 'trouser' \\
\hline / bistar / & / väirUn / & 'bedding' \\
\hline / kamzo:r / & / šus / & 'weak' \\
\hline / hamše:ri / & / beni / & 'sister' \\
\hline / bara:ðar / & / boi / & 'brother' \\
\hline / tUrUn / & / hŨðUr / & 'cold' \\
\hline / garə m / & / vUšUn / & 'hot' \\
\hline
\end{tabular}

\section{Variation Due To the Use of Modern, Scientific, and Technical Terminologies}

In order to enjoy a special status, and to be differentiated from the other speakers of the speech community, the speakers of the literate group (E1) and Age group A1 (15 - 50 years) tend to show great affinity to use the most prestigious and standardized variety of Kashmiri. For doing all this, these speakers borrow certain items of modern, scientific, and technical terminology/vocabulary from other languages, especially from English. This phenomenon enables them to enrich their lexical build and standardize the variety of their speech. The examples of the most commonly used borrowed (modern, scientific, and technical) terms found exclusively in the speech of the above mentioned groups of speakers are as following:

/ințarneț / 'internet' , / i:me:1 / 'email', / kampuțar / 'computer', / țe:b / 'tab', / țe:bleț / 'tablet', / aype:d / 'iPad', /aypod / ' iPod', / le:pta:p / ' laptop ', / selфo:n / 'cell phone', / фo:n nambar / 'phone number', / miska:1 / 'missed call', / mase:j / 'message', / esemes / 'SMS', / pe:par / 'newspaper', / kəla:s / 'class', / kəlasme:ț / 'classmate' / lekčar / 'lecture', / notəs / 'notes', / ekza:m / 'exam', / ekza:mnar /'examiner', / markəs / 'marks' / bUkəs / 'books' / ț iUš an / ' tution', / фivar / 'fever', / kold / 'cold' / ja:b / 'job', / ba:s / 'boss', / biznes / 'business', / done:šan / 'donation' / pa:rți: / 'party', / mi:țin / 'meeting', / prend / 'friend', / ba:y prend / 'boyfriend/ ', / gərəl prend / 'girlfriend', / prendšip / friendship', / hasbe:nd / 'husband', kičan / 'kitchen', / ba:Oru:m / 'bathroom', /bedru:m / 'bedroom', / šə:ț / 'shirt', /penț / 'pants', / ț i:šə:ț / 'T-shirt', / țravzar / 'trouser', / kəmi:z / 'shirt', / фla:iț / 'flight'/ injan / ' engine', / inji:nar / 'engineer' / avalse:r / 'overseer', / sUprãndãț / 'superintendent', / bil// 'bill', etc.

\section{E. Variation Due To the Use of Different Registers}

Another way of looking at the lexical variation is to study various lexical items associated with the occupation or profession of different occupational or professional groups of a particular speech community. Register is therefore, a set of lexical items associated with the occupation or profession of a particular occupational or professional group used for 
a specific purpose in a specific social environment. Among the Kashmiri speech community, the register used by one particular occupational or professional group is not only missing in the lexicon of other occupational or professional group, but has also been found mutually unintelligible among different groups of speakers . The examples showing variation due to the varying use of different registers are given below:

\section{Register of farming}

/zira: $\theta$ / 'crop/production', / khal / 'barn' , / toh / 'bran', / kom / 'bran' , / yan / 'irrigation furrow', / ga:n / 'cattle shed', / bUs /'chaff', / ðãðihavad / 'a pair of bulls', / ðãðivo:1 / ' a person who ploughs ', / đãova:yinY / ploughing', / yipəț / ' beam used with a plough' / me:nkh / 'peg', / фədira:vUn / 'harrowing', / OalkarinY / ‘ transplantation', / lonUn / 'harvesting', / pasil / 'crop/production', / pr:țh / 'furrow' /tsu:d / ' digging of soil', / və:r / 'kitchen garden' / nə:d / a big piece of agricultural land', / da:ni / 'rice/paddy', / dã:beyo:1 / 'paddy seeds', / dã:bu:hUrY / ' a sack of rice', / dã:kUțh / 'granary', / harUð / 'harvest season' /sagdiyUn / 'to irrigate', / pah / 'manure' gUh / 'manure' / greți / 'flour mill', / Өəjva:n / 'seed bed', / narsari: / 'nursery', / khəjyфal / 'oil cakes', / payvãð / 'grafting', / gi:nty / 'sheaf', / bi:lyči / 'shovel', / ðro:t / 'stickle', / livan' spade', / vavUn / 'sowing' / čhõmbUn / ' thrashing', nenði / 'wedding' / va:ф / ‘ a particular time and season for sowing a particular crop' etc.

\section{Register of medical profession}

/dakhţar / 'doctor', / nərəs / 'nurse', / bed /'bed', / apre:šan / operation', / injãkšan / 'injection' / kapšol / 'capsule' / si:rap / 'syrup', / maleriya / ' malaria', / țyфayid / 'typhoid', / alsar / 'ulcer', / bade:j / ‘ bondage', / palastar / 'plaster', / payip /, 'pipe', / wa:d / 'ward', / drasin /, / apran / 'apron', / sərjan /, 'surgeon', / ãmbUlanəs / 'ambulance', / haspata:1 /

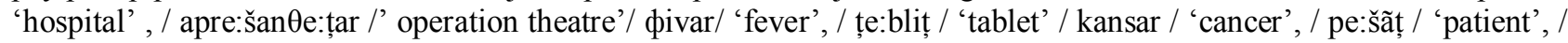
admiț / 'admit', / disča:rij / 'discharge', / pe:n / 'pain', / gUlikots /'glucose', / inфekšan / 'infection', etc.

\section{Register of law}

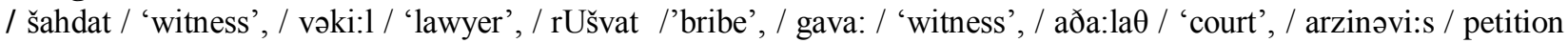
writer', / adava / ' 'enmity' / girvi / 'mortgage', / bahats / 'discussion', / jarah / 'counter argument' / jUrma:ni / 'penalty',

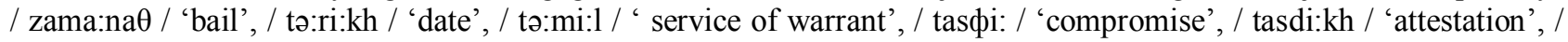
daфa / 'section', / dava: / 'claim', / dasta:ve: / 'document', / pi: ši: / 'hearing', / фə:sli / 'judgment', / mUda:i: / 'appellant' / bəri: / 'acquitted', / baya:n / 'statement' , / insa:ф / 'justice', / milzim / 'accused' / mijrim / 'criminal', / jUrUm / 'crime', / giriфtə:tri: / ' arrest/conviction’ /misal / ' file', / yišţiya:m / 'court stamp', / yišțiya;m фaro:š / 'stamp seller' /hakh / 'right', / milkiya / 'property' / pritshigə:r / 'enquiry', / halфibaya;n / ' affidavit' / sura:g / 'clue', / saza: / 'punishment' / je:1 / 'prison', / mUnsiф /'judge', / ko:nu:n / ‘law', / karvə:yi: / 'action', / khəla:ф varzi: / 'violation', etc.

\section{Register of boatmen and Fishermen}

/ khu:r / 'oar', / za:1 / ' net used for catching the fishes', / sag / 'rope used for holding the net while catching fishes', / Oambiged / 'upper part of the rope of the net', / ðoši / ' the upper part of the net', / parikar / 'pockets of the net', / sakhran / ' needle like tool used for weaving/knitting the net', / na:o / 'boat', / šikə:ry / ' small boat', / gadivə:r / ' small boat', / nam / 'front part of the boat', / dãb / 'middle portion of the boat' / kot / 'plug used to stop the entry of water inside the boat', / khot / ' a box like structure in the boat for keeping fishes', / ba:1 / 'river bank', / latidar / 'part of the boat where the boatman sits', / țhUpir / ' basket like structure used keep fishes for sale', etc.

\section{Register of Business and trade}

/ bapə:rY / 'businessman', / ba:p:r / 'business' / gra:kh / 'customer', / ba:v / ' price / rate', / soða: / 'deal', / sai: / 'advance', / ba:rða:n / ' empty boxes / cases', / ðõkhi / ' cheating', / ðõkhiba:z / ' cheater', / ja:lsa:z / 'cheater', / ðуа:naөð:r / 'honest', / ðadiðad / 'bargaining', / naфa / 'profit', / nokhsa:n / 'loss', / ma:1 / 'goods/products/fruits' / pasil / 'crop / fruit', / kariz / 'debt' / nakið / ' cash' /vozUm / ' borrow/ lend ', / ma:rkeț / ' market' / mãg /'demand', / tija:ra / 'trade' / tə:jir / 'trader/businessman', / mə:likh / 'owner', / dUlə:Y / ' labor/charges' / ðrojar / inflation' / srojar / 'cheapness' / kãdi / 'scale' / la:ga日 / 'charges', / taški:š / 'estimate', / mõdi: / 'market', / lo:n / 'loan', etc.

\section{DisCUSSIONS AND CONCLUSIONS}

\section{Findings}

Since language and society are closely related to each other, language variation takes place because of social variation. Kashmiri speakers belonging to different social groups have been observed to vary in the use of their language at the level of phonology and lexicon in accordance with certain social variables viz-a-viz, religion, education, region/ socioeconomic status, age and occupation/profession.

The sociolinguistic variables recorded on the basis of religion have divided the entire speech community into two groups of speakers viz. Hindu Kashmiri speakers and Muslim Kashmiri speakers. The Hindu Kashmiri speakers (HK) have been seen to vary considerably in the use of their language at the level of phonology and lexicon from their Muslim counterparts (MK). One of the reasons behind this variation is that the form of their speech (HK) has been found to be mostly filled with and influenced by Sanskrit sources and the form of the speech of the Muslim Kashmiri speakers (MK) has been observed to be enriched and influenced by Perso-Arabic borrowings. Moreover, the Hindu Kashmiri speakers irrespective education, region (urban/rural) and age. have been found to show a greater affinity towards the standard variety of Kashmiri . 
On the basis of education, we had literate (E1) and illiterate (E2) groups of speakers. While studying the variation in the use of their language, it has been found that the speakers of literate (E1) group of Kashmiri like the Hindu speakers (irrespective of the place of their living, age and education) tend to use the standard variety of the language in comparison with their illiterate (E2) counterparts. They have also been seen to undergo borrowings of a considerable number of modern, scientific and technical terms form other languages especially English, in order to enrich the variety of their speech and look different from their illiterate (E2) counterparts.

Variations recorded on the basis of age revealed that the two groups of speakers viz., A1 (15-50 years) and A2 (50 years and above) do not use the same pattern of language. Like the Hindu Kashmiri speakers (HK) and the speakers of the literate group (E1), the speakers belonging to age group (A1) i.e. 15 - 50 years, irrespective of their place of living/region and the socioeconomic status have been found to show their inclination towards enriching their speech with modern terminologies.

On the basis of urban and rural character of the speech, significant variations have been noted among the speakers of the Kashmiri speech community. The speakers hailing from the valley of Srinagar and its vicinity are of course urban in origin and use the urban variety of Kashmiri which in turn is the standard variety. This variety is different from the rural variety of Kashmiri used by the rural speakers (settled in other parts of the valley other than the city of Srinagar).

Different occupational groups of the Kashmiri speech community include: farmers, office goers (professors, school teachers, doctors, lawyers etc.), boatmen/ fishermen and businessmen/traders. Variations in the use of their language have been recorded and presented in terms of use of various registers related to the profession and occupation of each professional and occupational group. It has been observed that the lexical items used in the registers of these professional and occupational groups are not found in the everyday speech of the common people of the speech community. As a matter fact, they do not use these lexical items unless they are practically involved in the situation of related and concerned matters with the members of different occupational/professional groups of the speech community.

\section{Conclusion}

Linguistic variation is central to the study of language use. Different speakers of the same language have been seen to express the same meanings using different forms. Language variation is in fact the mirror reflection of the social variation. It is the direct consequence of the social variation of a heterogeneous speech community. The state of Jammu and Kashmir is the home to various sects of people. It inhibits the people belonging to different social backgrounds. Technically speaking, there is the social stratification and social heterogeneity. This social heterogeneity of the Kashmiri speech community is very well reflected in the linguistic behavior of its speakers. The speakers belonging to different social groups of the Kashmiri speech community do not use the same pattern and same structure of the language. They are bound to vary in their linguistic usage as they differ socially. The structure of the Kashmiri language therefore, considerably varies at various social levels of the Kashmiri speech community. For this variation among the Kashmiri speakers, certain social factors such as religion, region (place of living /socioeconomic level), education, age and occupation/ profession are widely held responsible.

\section{REFERENCES}

[1] Bayer, Jenifer Marie (1986). A Sociolinguistic investigation of English spoken by Anglo Indians in Mysore city. Mysore: Central Institute of Indian Languages.

[2] Bell, R. (1976). Sociolinguistics: Goals, Approaches and Problems. London, Bats ford.

[3] Bailey, Charles J.N. (1973). Variation and linguistic theory. Center for Applied Linguistics. University Of California.

[4] Brass, Paul R. (1975). Language religion and politics in North India. New Delhi: Vikas Publishing House.

[5] Bright, William (1976). Variation and change in language. by William, Bright selected and introduced by Anwar S.Dil. California: Stanford University Press.

[6] Dil, Anwar S. (1971b). Language in social groups. Essays by John J. Gumperz. Stanford: Stanford University Press.

[7] Ferguson, Charles A. (1959). Diaglossia. Word.15: 325-40

[8] Fischer, John L. (1958). Social influence on the choice of a linguistic variant. Word 14, 47 -56.

[9] Guperz, John J. (1958). Dialect differences and social stratification in North Indian Villages. American Anthropologist 6 : 66882 pp $25-47$.

[10] Grierson, Georg A. (1919). The Linguistic classification of Kashmiri. Indian Antiquary. Vol.44,257-70

[11] Hudson, R.A. (1980). Sociolinguistics. Cambridge: Cambridge University Press.

[12] Jaberg, Karl. (1936). Aspects geographique du langiage. Paris, Dorz.

[13] Kachru, Braj B. (1969). An introduction to spoken Kashmiri. Urbana: University of Illinois.

[14] Koul, O..N. (1969). "Perssainization of Kashmiri”. Urban: University of Illinois.

[15] Koul, Omkar N. (1977). Linguistic Studies in Kashmiri. Delhi: Bahri Publications.

[16] Koul,Omkar N and Ruth Laila Schmidt. (1983). Kashmiri: A Sociolinguistic Survey. Delhi: Indian Institute of Language Studies.

[17] Labov, William. (1963). The Social Motivation of Sound Change. Word 19 (1963), pp273-309.

[18] Labov, William. (1966b). 'The linguistic variable as a structural unit'. Paper presented before the Linguistic Club of Washington D.C. October Washington Linguists Review3: 4-22 (1966).

[19] Labov,William. (1966). The social stratification of English in New York City. Washington, D.C: Center for Applied Linguistics. 
[20] Labov, William. (1971). Variation in language. The learning of language, (ed.) Carroll E.Read. New York: Appleton Century Crafts, 1971 pp. 187-219.

[21] Labov, William. (1972). Sociolinguistic patterns. Philadelphia: University of Pennsylvania Press/Oxford: Basil Blackwell.

[22] Lusk, Melanie Marie. (1977). Phonological variation in Kansas City. A Sociolinguistic analysis of three generation families. Ann Arbor ,U.M.I.1977.

[23] Sapir, Edward. (1929). Language, culture and society. Berkeley: University of California Press.

[24] Trudgill, Petter. (1974). The social stratification of English in Norwich, London: Cambridge University Press.

[25] Trudgill, Petter. (1983). Sociolinguistics. An introduction to language and society. Revised edition. Harmondsworth: Penguin Books.

[26] Wardhaugh, Ronald. (1976). The contexts of language. Rowley, Massachusetts: Newburry House.

[27] Wardhaugh, Ronald. (1986). An introduction to sociolinguistics. Oxford: Basel Blackwell.

Nisar Ahmad Koka took his birth in Melahura, Distt. Shopion, Jammu and Kashmir, India, on March 1, 1971. He did his M.A. in theoretical linguistics in 1998, and was awarded the PhD degree in sociolinguistics by Aligarh Muslim University Aligarh, U.P. India in 2002. His major fields of study are theoretical linguistics, sociolinguistics, and language teaching (sub-area of applied linguistics).

He has worked on a couple of research projects and participated in considerable number of seminars and workshops concerned to language and linguistics. As a resource person he has also delivered lectures in various orientation and refreshing courses meant for second language teachers. Currently engaged as an Assistant Professor of linguistics at the Department of English, Faculty of Languages and Translation, King Khalid University Abha, Kingdom of Saudi Arabia, he has completed eleven years of his teaching career. He has to his credit several research articles. Innovative Kashmiri a language of news media. Published in Linguistics Today. Aligarh U.P. Volume No. 1 Jan.-Jul.2001 (p,87-93) in 2002, and Sociolinguistic impact of loanwords of the Arabic origin on the Urdu language, published in Language in India www.languageinindia.com (USA).Volume 13 : January 2013 (pp, 1006-1029) in 2013.are some of author's publications.

Dr. Koka was awarded Post Graduate Merit Scholarship and the Departmental Research Fellowship (DRF) while perusing his M.A. and $\mathrm{PhD}$ degrees respectively. 